\title{
Oil Prices and Stock Market: A Philippine Perspective
}

\author{
Sheevun Di O. Guliman \\ Faculty, Department of Accountancy, MSU - Iligan Institute of Technology \\ Andres Bonifacio Avenue, Tibanga, Iligan City, 9000, Philippines \\ E-mail: sheevundi.guliman@g.msuiit.edu.ph
}

Received: July 1, 2015 Accepted: July 28, 2015

doi:10.5296/ber.v5i2.7941ＵRL: http://dx.doi.org/10.5296/ber.v5i2.7941

\begin{abstract}
Oil prices and stock markets play vital functions to a country's economic condition. Thus, this study examines the dynamic relationship between the inflation adjusted Philippine Stock Exchange index (PSEi) prices and real oil prices in Philippine peso using monthly data from January 1996 to December 2014 applying the Vector Autoregression (VAR) Model. Granger Causality Test, Impulse Response Functions (IRFs) and Forecast Error Variance Decomposition (FEVD) were also used to aid in the analyses of the results. The results of this study suggest that there is no significant relationship between the monthly inflation adjusted stock prices of the PSEi and monthly real oil prices in peso. This paper offers guidance to the investors that the real oil prices do not significantly Granger-cause the movement of the monthly prices of the PSEi. It is suggested that the dynamic relationship between oil prices, industrial production and share prices of sector indices in the Philippines that are highly oil-dependent be investigated in future research considering the oil demand and supply shocks.
\end{abstract}

Keywords: Oil price, Stock market, Vector Autoregression, Philippines

\section{Introduction}

Oil plays an essential function in a country's economic growth. Nonetheless, not all countries have sufficient oil supply, which necessitates them to buy from the world market and be exposed to oil price volatility. Considering that oil is a depleting and a highly demanded global commodity, fluctuations in its prices may cause an impact on several macroeconomic variables such as exchange rates, interest rates, inflation rates, aggregate demand and it may even influence the performance of a country's stock market. Huang, Masulis and Stoll (1996) suggested a theoretical link between oil prices and stock prices. These authors reasoned that a rise (fall) in oil price increases (decreases) the expenses of the company; thereby decreasing 
(increasing) its free cash flows and subsequently decreases (increases) the company's share prices. Huang et al. (1996) also argued that oil prices might affect expected inflation rates and interest rates thereby affecting also the discount rates used in share price valuation. More often than not, if stock prices decrease, stock returns may also decrease since stock return is a function of capital gains yield caused by the changes in stock prices plus the dividend yield of the stock. Studies have shown that there is a strong and positive relationship between stock market development and long run economic growth (Levine \& Zervos, 1996; Beck \& Levine, 2004; Shahbaz, Ahmed \& Ali, 2008). Therefore, a stock market's performance can be used as a gauge for a country's economic growth. Consequently, a resilient (depressed) stock market due to rising (declining) share prices may positively (negatively) affect the economic condition of a country. In recent years, the relationship between oil price to select macroeconomic variables and stock markets has been one of the more studied subjects in the fields of economic and finance. However, there is a shortage of research as to this relationship in the Philippine context.

Results of the studies with regard to the relationship between oil prices and stock markets are not unanimous. A number of studies suggested an inverse relationship between oil price and stock market performance, particularly on the stocks' returns of the developed economies (Jones \& Kaul, 1996; Sadorksy, 1999; Chen, 2009; Filis, 2010; Cunado \& Perez de Garcia, 2014). On the contrary, some studies also found a positive relationship between oil price and stock markets of the developed economies (Sadorsky, 2001; Constantinos et al., 2010; Abdalla, 2013; Hasan \& Mahbobi, 2013). Nonetheless, Apergis and Miller (2009) and Jammazzi and Aloui (2010) showed no significant relationship between oil price and stock market returns of the developed economies they have studied.

Results for emerging countries also vary. For instance, some studies found an inverse relationship between oil price and stock markets of emerging economies (Basher et al., 2012; Asteriou \& Bashmakova, 2013; Gupta \& Modise, 2013). Fang and You (2014) also argued that so long as the oil price is "not driven by the increasing oil consumption of India, the oil prices always have a negative impact on India's economy” (p. 337). However, Chaudary, et al. (2014) asserted that the "share prices of Nigerian companies respond positively to the world market and oil prices" (p. 781). For those countries belonging to the Gulf Cooperation Council (GCC), Hammoudeh and Choi (2007) and Arouri \& Rault (2012) also found a positive relationship between oil price and GCC stock markets. In the case of the member countries of the Association of South East Asian Nations (ASEAN) like Vietnam, Narayan and Narayan (2010) revealed that oil prices and exchange rates have significant positive effect on stock prices using daily data. In Indonesia, also an ASEAN country of which Philippines is also a member, Adam et al. (2015) also found a positive relationship between daily oil prices and Indonesian Stock Exchange. In contrast, there are also studies, which showed that there is no significant relationship between oil price and emerging stock markets (Unal \& Korman, 2012; Kang \& Yoon, 2013). In the case of the leading emerging economies, the results of Gay Jr. (2008) also revealed that there is "no significant relationship between respective exchange rate and oil price on the stock market index prices of either BRIC country" (p. 1). In fact, Sehgal and Kapur (2012) also contended that the "high-growth 
emerging economies tend to provide positive market returns disregarding the nature of oil price shocks (positive or negative)" (p. 87). This means that irrespective of how the oil moves, as long as the emerging economy is strong, stock markets will still provide positive returns since the performance of the stock market is not dependent on oil price fluctuations.

In some studies where the Philippines is one of the emerging countries being investigated, results also vary. For instance, Maghyereh (2004) found that in general, the daily stock market returns from 1998 to 2004 in 22 emerging economies do not reasonably signal shocks in the crude oil market using VAR model. In contrast, Basher and Sadorsky (2006) investigated the daily data from 1992 to 2005 of 21 emerging countries using an international multi-factor model found "strong evidence that oil price risk impacts stock price returns in emerging markets although the exact relationship depends somewhat on the data frequency being used" (p. 249). Also, Nandha and Hammoudeh (2007), using weekly data from 1994 to 2004 and also employing an international multi-factor model, found out that only Philippines and South Korea out of the 15 countries in the Asia Pacific region are sensitive to changes in the oil price in the short run if expressed in the local currency but no country is found to be oil-sensitive if expressed in US Dollars. Aloui, Nguyen and Njeh (2012) also analyzed the daily data of 25 emerging countries from 1997 to 2007 and classified these countries as to the largest oil-exporting countries, largest oil-importing counties and moderately oil-dependent using an international multi-factor model. Aloui et al. (2012) classified the Philippines as one of the moderately oil-dependent emerging countries and they suggested that there is a "significant and positive relationship between oil-related beta and stock returns in moderately oil-dependent countries during bullish markets" (p. 2687).

The possible differences of various studies can be attributed to what drives the oil price shocks as posited by Basher and Sadorsky (2006); Kilian and Park (2009); Abhyankar, Xu and Wang (2013); and Fang and You (2014). The possible differences may also be attributed to whether a country is a net oil-importer or net oil-exporter as explained by Wang, Wu and Yang (2013). As mentioned, Basher and Sadorsky (2006) argued that the exact relationship of their findings is dependent on the frequency of data they used. Kilian and Park (2009) also contended that stock market returns are not affected by the supply-side oil price shocks yet returns have negative reaction to specific demand-side oil price shocks and react positively to aggregate demand oil price shocks. Abhyankar, Xu and Wang (2013) also posited that "oil price shocks that arise from changes in aggregate global demand are positively correlated to returns on the Japanese stock market [but] Japanese stock market reacts negatively to oil price increases related to oil-market specific demand shocks" (p. 199). In the same way, Fang \& You (2014) asserted that "an oil price driven by global oil demand shocks has an insignificant effect, and China's oil -specific demand-driven oil price has a significant negative effect during the $3^{\text {rd }}$ to 6 months" (p. 337). On one hand, Wang et al. (2013) contended that the "positive aggregate and precautionary demand shocks are shown to result in a higher degree of co-movement among the stock markets in oil-exporting countries, but not among those in oil-importing countries" (p. 1220).

This paper intends to examine the dynamic relationship between the real oil price in peso and the inflation adjusted share prices of the Philippine Stock Exchange Index (PSEi) applying 
the Vector Autoregression (VAR) Model. Considering that the Philippines is a net oil-importer, this study aims to be relevant by providing an understanding on how real oil prices influence the stock index prices to help investors and other financial market players in their decision-making considering a particular situation.

The rest of this paper is organized as follows. Section 2 provides an overview on the Philippine Stock Exchange and Section 3 describes the methodology employed. Section 4 of this paper contains the results and discussion of the study and Section 5 concludes the paper.

\section{Philippine Stock Exchange}

The Philippine Stock Exchange (PSE) is the sole stock exchange in the Philippines and was formally recognized on December 23, 1992. The PSE was formed after the integration of the two formerly separate stock exchanges, the Manila Stock Exchange (MSE) and the Makati Stock Exchange (MkSE). The unification was done to further the development of the Philippine capital market. The PSE maintains the PSEi, the All Shares Index and six sector indices namely: Industrial; Properties; Services; Holding Firms; Financials; and Mining \& Oil Sectors. At the end of 2014, the listed companies of the PSE consist of 30 financial firms, 65 industrial firms, 41 holding firms, 39 property companies, 58 firms from the services sector and 26 mining \& oil companies (PSE Edge, 2014).

On one hand, the PSE adopted the PSEi in April 2006 as the primary index of the Philippines although it was earlier labeled as Phisix and PSE Composite Index. The PSEi comprises a fixed basket of 30 largest and most active equity listed in the Philippines and its reckoning base date is February 28, 1990 (PSE, 2011). The PSE conducts semi-annual reviews on the composition of the companies included in the PSEi. Table 1 below shows the list of the companies constantly included in the semi-annual PSEi re-composition as tallied by the author from the PSE circulars and annual reports.

Table 1. List of companies constantly included in every semi-annual PSEi re-composition

\begin{tabular}{|l|l|}
\hline Name & Sector \\
\hline Aboitiz Equity Ventures, Inc. & Holding Firms \\
\hline Ayala Corporation & Holding Firms \\
\hline Ayala Land, Inc. & Property \\
\hline BDO Unibank, Inc. & Financials \\
\hline Bank of the Philippine Islands & Financials \\
\hline Globe Telecom, Inc. & Services \\
\hline International Container Terminal Services Inc. & Services \\
\hline Jollibee Foods Corporation & Industrial \\
\hline Manila Water Company, Inc. & Industrial \\
\hline Metropolitan Bank \& Trust Company & Financials \\
\hline Megaworld Corporation & Property \\
\hline Philippine Long Distance Telephone Company & Services \\
\hline SM Investments Corporation & Holding Firms \\
\hline SM Prime Holdings, Inc. & Property \\
\hline
\end{tabular}


As seen in Table 1, the country's premier holding firms, the two largest telecommunication companies, the three Philippine largest banks and the country's largest food corporation regularly occupy the slots in the PSEi in every semi-annual re-composition from 2006 to 2014. This goes to show that despite the reevaluation, 14 out of the 30 companies included in the PSEi are regularly included in the index. Table 1 only covers from 2006 when the label PSEi was adopted by the PSE as mentioned above until the end of 2014. Furthermore, Table 2 shows the number of companies in the PSEi, which were classified according to sectors to be able to get a profile of the PSEi composition.

Table 2. Number of companies from each sector in the PSEi semiannual re-composition

\begin{tabular}{|c|c|c|c|c|c|c|c|c|c|c|c|c|c|c|c|c|c|c|}
\hline \multirow[t]{2}{*}{ Sector } & \multicolumn{2}{|c|}{2006} & \multicolumn{2}{|c|}{2007} & \multicolumn{2}{|c|}{2008} & \multicolumn{2}{|c|}{2009} & \multicolumn{2}{|c|}{2010} & \multicolumn{2}{|c|}{2011} & \multicolumn{2}{|c|}{2012} & \multicolumn{2}{|c|}{2013} & \multicolumn{2}{|c|}{2014} \\
\hline & A & B & A & B & A & B & A & B & A & B & A & B & A & B & A & B & A & B \\
\hline Financials & 4 & 5 & 5 & 3 & 6 & 5 & 4 & 5 & 5 & 4 & 4 & 3 & 3 & 3 & 3 & 3 & 3 & 3 \\
\hline Holding Firms & 7 & 7 & 6 & 6 & 5 & 5 & 5 & 6 & 6 & 7 & 7 & 8 & 8 & 8 & 8 & 10 & 10 & 10 \\
\hline Industrials & 5 & 6 & 8 & 9 & 8 & 8 & 8 & 8 & 7 & 8 & 8 & 6 & 7 & 8 & 8 & 7 & 7 & 8 \\
\hline Mining \& Oil & 3 & 3 & 3 & 2 & 2 & 2 & 2 & 2 & 2 & 2 & 2 & 2 & 2 & 2 & 2 & 2 & 2 & 1 \\
\hline Property & 6 & 5 & 4 & 6 & 6 & 6 & 6 & 5 & 5 & 5 & 5 & 7 & 6 & 6 & 5 & 4 & 4 & 4 \\
\hline Services & 5 & 4 & 4 & 4 & 3 & 4 & 5 & 4 & 5 & 4 & 4 & 4 & 4 & 3 & 4 & 4 & 4 & 4 \\
\hline
\end{tabular}

The companies included in the PSEi are representatives of the six sectors mentioned. As shown in Table 2, most companies in the PSEi come from the holding firms and industrial sectors as tallied by the author from the PSE circulars and annual reports. In fact, towards the recent years, holding firms dominate the PSEi composition. At the end of 2014, the PSEi is composed of ten holding firms, seven from industrials sector, five from services sector, four from property sector, three from financials sector and one from mining and oil sector (PSE, 2014).

\section{Methodology}

\subsection{Data Description and Sources}

The sample consists of monthly data from January 1996 until December 2014. The oil prices are to be deflated using the Philippine Consumer Price Index (CPI) to obtain its real price. Given that Philippine CPIs are released monthly at the very least, this prompted the author to use monthly data instead of using daily or weekly data. Other studies that used monthly data were Basher et al. (2012); Wang et al. (2013); Abhyankar et al. (2013); Gupta and Modise (2013); Cunado and Perez de Garcia (2014); and Fang and You (2014), among others. It must be recalled that the Asian Financial Crisis was triggered in July 1997. Nonetheless, signs were already showing as early as spring of 1996 when the Southeast Asia's growth in export slowed down considerably which deteriorated the region's current account position (Goel, 2009). The Philippines, on the other hand, "endured the crisis relatively more successfully than its neighbors" (Noland, 2000, p. 401-402). This goes to show that the Philippines was more resilient relative to its neighboring countries even during the Asian financial crisis. It is for this reason that the data spanned from January 1996 to December 2014. The West Texas 
Intermediate (WTI) world oil prices in US Dollars were taken from the database of World Bank and were converted to Philippine peso using the monthly end of period exchange rate from the data bank of the Bangko Sentral ng Pilipinas (BSP).

As mentioned, the oil prices in peso were deflated using the all-item Philippine CPI, which were also lifted from the BSP data bank. The monthly closing prices of PSEi in peso were taken from the Wall Street Journal and were deflated using the CPI to get the inflation-adjusted real values as suggested by Wang et al. (2013). The PSEi is used in this study because it is the primary index in the Philippines. Other studies, which also used stock/equity indices instead of select companies were Sadorsky (1999); Basher and Sadorsky (2006); Park and Ratti (2008); Apergis and Miller (2009); and Masih, Peters and De Mello (2011).

\subsection{Model Specification}

\subsubsection{Lag Selection}

VAR results are highly sensitive to the lag lengths being used in running the model (Brooks, 2008). Hence, to mitigate this potential problem, the proposed variables to be included in the VAR model were simultaneously subjected to the lag-order selection statistics (pre-estimation) to determine the appropriate number of lags when running the subsequent tests.

Results showed that all information criteria such as Final Prediction Error (FPE), Akaike Information Criterion (AIC), Schwarz's Bayesian information criterion (SBIC), Hannan and Quinn information criterion (HQIC) concurrently suggested using two lags as the appropriate lag length. Thus, all subsequent tests will use two lags as suggested by the information criteria presented.

\subsubsection{Unit Root Tests}

It is standard in the literature that time series data are supposed to be stationary prompting this study to employ the Augmented Dickey - Fuller (ADF) test to check if the datasets at their level forms have unit roots which may create problems of autocorrelation. Results of the ADF test showed that both variables are non-stationary at level form. Hence, to correct this problem, both variables were converted into first differenced forms to mitigate the problem of non-stationary time series data. The first differenced variables were also subjected to the ADF test and results showed that all first differenced variables are now stationary and it no longer contain unit roots at $99 \%$ confidence level.

\subsubsection{Cointegration Test}

Cointegration is an important concept in time series analysis since it has a bearing on the choice of the model to be used. This paper made use of the Johansen test to examine whether a long-run association between variables exists and to examine the presence of cointegrating relationships in the data. Given that all variables at their level forms are non-stationary but became stationary when transformed to first differences; hence, the precondition to apply the Johansen test was met. The null hypothesis in the Johansen test states that there is no cointegration among variables and the alternative hypothesis states that there is cointegration 
among variables. Results showed a trace statistic of 9.6948 compared to the critical value of 15.41 at maximum rank 0. Also, the maximum eigenvalue statistic is 7.5676 compared to the critical value at 14.07 at maximum rank 0 . Based from the results, both the trace statistic and maximum eigenvalue statistic are less than the critical values at maximum rank 0 . Hence, we could not reject the null hypothesis. This means that there is no cointegration among the variables and that there is no long-run association between the variables. Results of the Johansen cointegration test suggest that the appropriate model to be used will be the unrestricted VAR.

\subsubsection{VAR System Model}

VAR is one of the usually applied models in time-series, which is non-structural, and variables can be treated identically as endogenous. The forecast made from a VAR model is often better than the restricted structural models although its drawbacks often include the sensitivity of VAR results to lag lengths and would need other techniques to facilitate its interpretation (Brooks, 2008). Despite many criticisms against VAR, Sims (1980) argued that VARs deliver a more systematic method to imposing constraints and may capture empirical regularities that may not be available to standard procedures. Other studies, which also used the VAR model, were Huang et al. (1996), Sadorsky (1999), Maghyereh (2004), Ono (2011), Seghal and Kapur (2012) and Soucek and Todorova (2013) among others.

The following equations describe a system in which each variable is a function of its own lags, and the lag of the other variable in the system. In this case, the system contains two variables ROPP and IAPSEi. Together the equations constitute a system known as VAR. Thus, this study will make use of the following VAR System Model as shown in equations 1 and 2 below:

$$
\begin{gathered}
R O P P=\beta_{0}+\beta_{1} \text { IAPSEi }_{t-1}+\beta_{2} \text { ROPP }_{t-1}+\beta_{3} \text { IAPSEi }_{t-2}+\beta_{4} \text { ROPP }_{t-2}+u_{1} \\
\text { LAPSE } i=\beta_{5}+\beta_{6} \text { ROPP }_{t-1}+\beta_{7} \text { IAPSE }_{t-1}+\beta_{8} \text { ROPP }_{t-2}+\beta_{9} \text { IAPSE }_{t-2}+u_{2}
\end{gathered}
$$

Where, ROPP is the first differenced of the real oil price in peso with its own lags; IAPSEi is the first differenced of the Inflation- Adjusted PSEi with its own lags; $\beta_{i}$ are the coefficient matrices and $u_{t}$ are error terms.

\subsubsection{VAR diagnostics}

The VAR System Model using the first differenced forms was also tested for any possibility of autocorrelation using the Lagrange-multiplier test. Results showed that the p value of Lag 1 and Lag 2 are 0.83122 and 0.68585 respectively. This means that there are no autocorrelation in both lag orders; hence, the model is well specified. The model was also subjected to the Jarque-Bera test to check whether residuals are normally distributed. Results showed that the residuals of both variables are not normally distributed. Nevertheless, when 
the model was examined for the stability condition of VAR estimates, all the eigenvalues appeared to lie inside the unit circle. Hence, the VAR model satisfies stability condition. This stability of the VAR model is very important to be able to apply the Impulse Response Functions (IRFs) and Forecast Error Variance Decompositions (FEVDs) to aid in the interpretation of the VAR results.

\section{Results and Discussion}

Results of the VAR are presented in Table 3. To be able to examine if the lagged variables jointly Granger-cause the dependent variable, the Granger Wald Test was also employed as displayed in Table 4.

Table 3. Results of Vector Autoregression

\begin{tabular}{|l|l|l|l|}
\hline Dependent variable & Lagged variable & Coefficient & $\mathrm{P}>|\mathrm{z}|$ \\
\hline \multirow{5}{*}{ ROPP } & ROPP L1 & 0.315 & $0.000 * * *$ \\
\cline { 2 - 4 } & ROPP L2 & 0.060 & 0.378 \\
\cline { 2 - 4 } & IAPSEi L1 & 0.030 & 0.638 \\
\cline { 2 - 4 } & IAPSEi L2 & -0.033 & 0.611 \\
\cline { 2 - 4 } & _cons & 1.428 & 0.915 \\
\hline IAPSEi & ROPP L1 & -0.016 & 0.816 \\
\cline { 2 - 4 } & ROPP L2 & 0.064 & 0.358 \\
\cline { 2 - 4 } & IAPSEi L1 & 0.117 & 0.079 \\
\cline { 2 - 4 } & IAPSEi L2 & 0.012 & 0.859 \\
\cline { 2 - 4 } & _cons & 0.325 & 0.981 \\
\hline ***significant at $99 \% ; * *$ significant at $95 \%$ & \multicolumn{2}{|l}{} \\
\hline
\end{tabular}

Table 3 suggests that only the lag 1 of the Real Oil Price in Peso (ROPP) is significantly related to the dependent variable ROPP with a coefficient of 0.315 . Both lagged variables of the Inflation-Adjusted PSEi (IAPSEi) are not significantly related to ROPP and vice versa.

Table 4. Results of Granger causality Wald Test

\begin{tabular}{|l|l|l|l|}
\hline Equation & Excluded & Chi2 & Prob>chi2 \\
\hline ROPP & IAPSEi & 0.430 & 0.807 \\
\hline IAPSEi & ROPP & 0.848 & 0.655 \\
\hline$* * *$ significant at $99 \% ; * *$ significant at $95 \%$ \\
\hline
\end{tabular}

The Granger Wald Test in Table 4 showed that the real oil prices in peso do not significantly Granger-cause the movement of the inflation-adjusted PSEi prices. In the same way, PSEi share prices do not significantly Granger-cause the real oil prices in peso. In this paper, only the lagged 1 of the real oil price in peso is found to be significant to affect the dependent variable ROPP yet its joint lagged showed to be insignificant based on the results of the Granger causality Wald test.

The IRFs, which showed the outcome of shocks on the adjustment path of the variables for 12 periods, is seen in Figure 1. Also, the FEVDs, which determine the contribution of each 


\section{NI Macrothink}

Business and Economic Research

ISSN 2162-4860

2015, Vol. 5, No. 2

type of shock to the forecast error variance for 12 periods is presented in Figure 2. IRFS and FEVDs are useful in gauging how shocks to economic variables reverberate within a system.

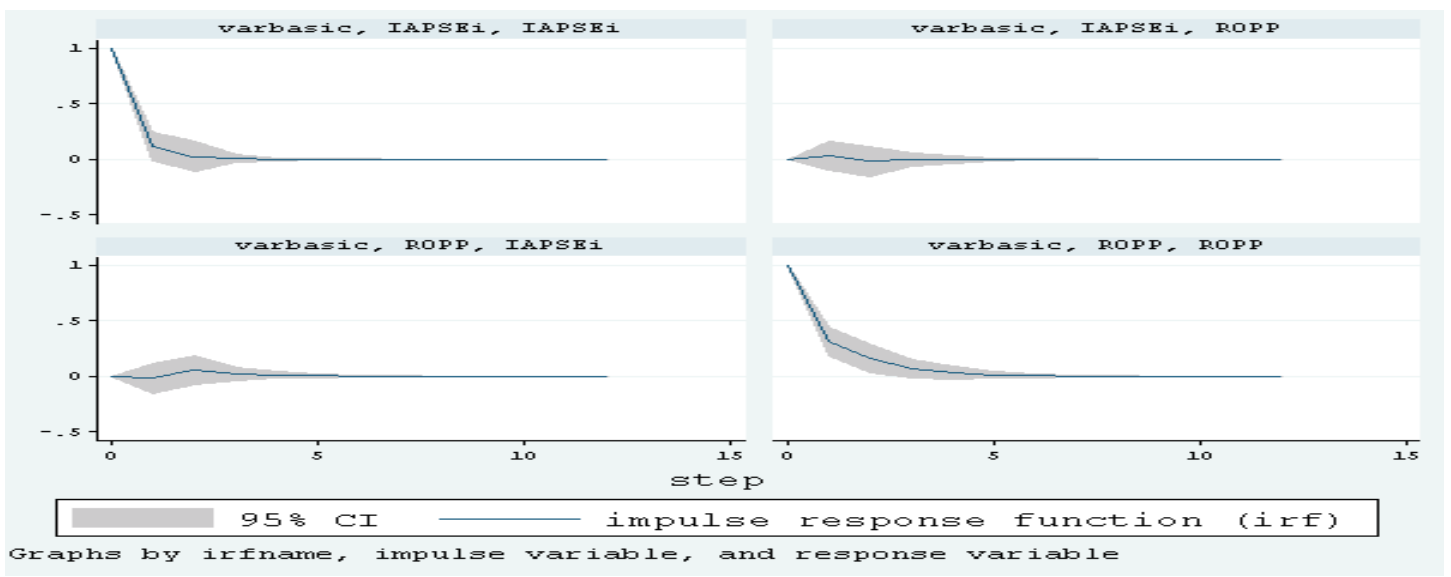

Figure 1. Impulse Response Function

In Figure 1, IRFs appear in four quadrants. In quadrant one (northwest) is the response in IAPSEi to a shock in itself. Since this series is stationary, the shocks are not persistent and effects eventually die out. The second quadrant (northeast) shows how a shock to IAPSEi affects ROPP while the third quadrant (southwest) shows how a shock to ROPP affects IAPSEi. Lastly, the fourth quadrant (southeast) shows the response of ROPP to a shock in itself. Figure 1 shows that the impact of an IAPSEi shock on the time path of ROPP creates a very minor response but it is not persistent and their effects ultimately die out quickly. The impact of a shock on ROPP on the time path of IAPSEi also creates a very slight response but is also found to be not persistent and it falls to zero very swiftly.

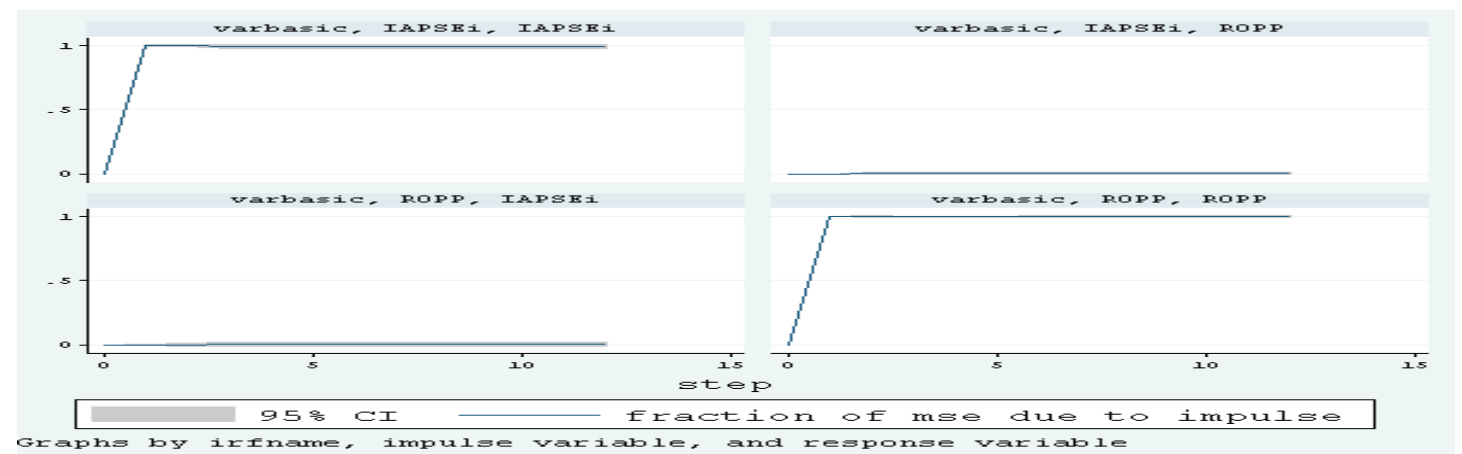

Figure 2. Forecast Error Variance Decomposition

In Figure 2, the fraction of the mean squared error (mse) of the impulse variable (ROPP) to the response variable (IAPSEi) is zero. In the same way, the fraction of the mse of the impulse variable (IAPSEi) to the response variable (ROPP) is also zero.

Results of this paper offer support to the study of Maghyereh (2004), which also employed VAR method, that there is no relationship between the daily stock market prices that are dominated in US dollar from the Morgan Stanley Capital International (MSCI) and Brent oil prices of emerging markets. The results of Maghyereh (2004), which included the Philippines 
as one of the emerging markets, suggested that it is likely that the "emerging economies are inefficient in transmission of new information of the oil market" (p. 37). Maghyereh (2004) also cited that "emerging economies do not rationally signal changes in the crude oil prices" (p. 38). Other studies that suggested that there is no relationship between stock markets and oil prices are Gay Jr., 2008; Apergis and Miller, 2009; Jammazzi and Aloui, 2010; Unal and Korman, 2012; Kang \& Yoon, 2013.

This paper provides guidance to investors and other financial market players that the real oil prices in peso do not significantly affect the prices of PSEi. This suggests that fluctuations in the real price of oil in peso are not supposed to lead an investor to excessively worry since it does not significantly Granger-cause the movement of the monthly PSEi's share prices. The results also propose that the investors and financial market players' decision to either buy or sell shares that are indexed to the PSEi is not necessarily affected by the fluctuation of the oil price. Even Seghal and Kapur (2012) maintained that it is economic growth and prosperity that seems to drive the stock prices and not necessarily oil prices. These authors further stated, "the emerging stock market behaviour, therefore, seems to be immune to the direction of oil shocks owing to the oil price determination process" (p. Seghal \& Kapur, 2012, p. 87). Over the years, a number of companies included in the PSEi are not necessarily highly oil-dependent such as those representing the financial and holding-firms sectors, which can be a factor why the results suggested that there is no relationship between PSEi share prices and oil prices.

\section{Conclusion}

The Philippines, being one of the emerging economies, is a fast growing ASEAN member country. Thus, the country's growth may likely influence the dynamics between oil prices and stock market. The dynamics between these variables are analyzed using an unrestricted VAR to examine the relationship in the Philippine context. Results of this study suggest that there is no significant relationship between oil prices and the PSEi share prices and that they do not Granger-cause each other. The impulse response functions also showed that the shock on the real oil prices creates a very minor response on the IAPSEi but it is not persistent and the effects ultimately die out quickly. Similarly, shocks on the PSEi share prices also create a minor response on the ROPP, which is also not persistent and falls to zero very swiftly. It is suggested that future studies be made on sector indices that is heavily reliant on oil consumption or oil imports such as industrial sector or mining and oil sector. Other literature focused on the relationship between oil price and stock market returns considering the effects of oil demand shocks or oil supply shocks, which the author leave it as an avenue for future researches. Also, it is suggested for future research that the relationship between oil price and industrial production be studied to validate whether the findings of other studies hold true in the Philippine setting.

\section{References}

Abdalla, S. (2013). Modelling the Impact of Oil Price Fluctuations on the Stock Returns in an Emerging Market: The Case of Saudi Arabia. Interdisciplinary Journal of Research in Business, 2(10), 10-20. 
Abhyankar, A., Xu, B., \& Wang, J. (2013). Oil Price Shocks and the Stock Market: Evidence from Japan. Energy Journal, 34(2), 199-222. http://dx.doi.org/10.5547/01956574.34.2.7

Adam, P., Rianse, U., Cahyono, E., \& Rahim, M. (2015). Modeling of the Dynamics Relationship between World Crude Oil Prices and the Stock Market in Indonesia. International Journal of Energy Economics and Policy, 5(2), 550-557.

Aloui, C., Nguyen, D. K., \& Njeh, H. (2012). Assessing the impacts of oil price fluctuations on stock returns in emerging markets. Economic Modelling, 29, 2686-2695. http://dx.doi.org/10.1016/j.econmod.2012.08.010

Apergis, N., \& Miller, S. (2009). Do Structural Oil-market Shocks Affect Stock Prices?. Energy Economics, 31(4), 569-575. http://dx.doi.org/10.1016/j.eneco.2009.03.001

Arouri, M., \& Rault, C. (2012). Oil prices and stock markets in GCC countries: empirical evidence from panel analysis. International Journal of Finance and Economics, 17, 242-253. http://dx.doi.org/10.1002/ijfe.443

Asteriou, D., \& Bashmakova, Y. (2013). Assessing the impact of oil returns on emerging stock markets: A panel data approach for ten Central and Eastern European Countries. Energy Economics, 38, 204- 211. http://dx.doi.org/10.1016/j.eneco.2013.02.011

Basher, S., \& Sadorksy, P. (2006). Oil price risk and emerging stock markets. Global Finance Journal, 17 (2), 224-251. http://dx.doi.org/10.1016/j.gfj.2006.04.001

Basher, S., Haug, A. \& Sadorksy, P. (2012). Oil prices, exchange rates and emerging stock markets. Energy Economics, 34, 227-240. http://dx.doi.org/10.1016/j.eneco.2011.10.005

Basnet, H. C., Vatsa, P., \& Sharma, S. (2014). Common Trends and Common Cycles in Oil Price and Real Exchange Rate. Global Economy Journal, 14(2), 249-263. http://dx.doi.org/10.1515/gej-2013-0042

Beck, T., \& Levine, R. (2004). Stock markets, banks, and growth: Panel evidence. Journal of Banking and Finance, 28(3), 423- 442. http://dx.doi.org/10.1016/s0378-4266(02)00408-9

Brooks, C. (2008). Introductory Econometrics. New York, United States of America: Cambridge University Press

Chaudary, S., Nisar, S., Talat, A., \& Salvador-Adebayo, D. (2014). Stock Market a Proxy for Oil Prices - A Focus on the Nigerian Economy. Pakistan Journal Of Commerce \& Social Sciences, 8(3), 780-797.

Chen, S. S. (2009). Do higher oil prices push the stock market into bear territory? Energy Economics, 32(2), 490-495. http://dx.doi.org/10.1016/j.eneco.2009.08.018

Constantinos, K., Ektor, L. A., \& Dimitrios, M. (2010). Oil Price And Stock Market Linkages In A Small And Oil Dependent Economy: The Case Of Greece. Journal of Applied Business Research, 26(4), 55-64.

Cunado, J., \& Perez de Garcia, F. (2014). Oil price shocks and stock market returns: Evidence 
for some European countries. Energy Economics, 42, 365-377. http://dx.doi.org/10.1016/j.eneco.2013.10.017

Fang, C., \& You, S. (2014). The impact of oil price shocks on the large emerging countries' stock prices: Evidence from China, India and Russia. International Review of Economics and Finance, 29, 330-338. http://dx.doi.org/10.1016/j.iref.2013.06.005.

Filis, G. (2010). Macro economy, stock market and oil prices: Do meaningful relationships exist among their cyclical fluctuations? Energy Economics, 32(4), 877-886. http://dx.doi.org/10.1016/j.eneco.2010.03.010

Gay, Jr., R. (2008). Effect of Macroeconomic Variables On Stock Market Returns For Four Emerging Economies: Brazil, Russia, India, And China. International Business \& Economics Research Journal, 7(3), 1-8.

Goel, S. (2009). Crisis Management: Master the Skills to Prevent Disasters. New Delhi: Global India Publications Pvt Ltd.

Gupta, R., \& Modise, M. P. (2013). Does the source of oil price shocks matter for South African stock returns? A structural VAR approach. Energy Economics, 40, 825-831. http://dx.doi.org/10.1016/j.eneco.2013.10.005

Hammoudeh, S., Choi, K. (2007). Characteristics of permanent and transitory returns in oil-sensitive emerging stock markets: the case of GCC countries. Journal of International Financial Markets, Institutions and Money, 17, 231-245. http://dx.doi.org/10.1016/j.intfin.2005.11.002

Hasan, S., \& Mahbobi, M. (2013). The increasing influence of oil prices on the Canadian stock market. The International Journal of Business and Finance Research, 7(3), 27 -39

Huang, R. D., Masulis, R. W., \& Stoll, H. R. (1996). Energy shocks and financial markets. $\begin{array}{lllll}\text { Journal of } \quad \text { Futures } & \text { Markets, } & 16, & 1-27 .\end{array}$ http://dx.doi.org/10.1002/(sici)1096-9934(199602)16:1<1::aid-fut1>3.3.co;2-g

Jammazi, R., Aloui, C. (2010). Wavelet decomposition and regime shifts: assessing the effects of crude oil shocks on stock market returns. Energy Policy, 38, 1415-1435. http://dx.doi.org/10.1016/j.enpol.2009.11.023

Jones, M. C., \& Kaul, G. (1996). Oil and stock markets. Journal of Finance, 51(2), 463-491. http://dx.doi.org/10.1111/j.1540-6261.1996.tb02691.x

Kang, S., \& Yoon, S. (2013). Return and Volatility Transmission Between Oil Prices and Emerging Asian Markets. Seoul Journal of Business, 19(2), 73-93.

Kilian, L., \& Park, C. (2009). The impact of oil price shocks on the U.S. stock market. $\begin{array}{llll}\text { International Economic } & \text { Review, } & \text { 50(4), } & \text { 1267-1287. }\end{array}$ http://dx.doi.org/10.1111/j.1468-2354.2009.00568.x

Kin, S., \& Courage, M. (2014). The Impact of Oil Prices on the Exchange Rate in South Africa. Journal of Economics, 5(2), 193-199. 
Levine, R., \& Zervos, S. (1996). Stock Market Development and Long-Run Growth. World Bank Economic Review, 10 (2), 323- 339. http://dx.doi.org/10.1093/wber/10.2.323

Maghyereh, A. (2004). Oil price shocks and emerging stock markets: A generalized VAR approach. International Journal of Applied Econometrics and Quantitative Studies, 1(2), 27-40.

Masih, R., Peters, S., \& De Mello, L. (2011). Oil price volatility and stock price fluctuations in an emerging market: Evidence from South Korea. Energy Economics, 33, 975-986. http://dx.doi.org/10.1016/j.eneco.2011.03.015

Nandha, M., \& Hammoudeh, S. (2007). Systematic risk, and oil price and exchange rate sensitivities in Asia-Pacific stock markets. Research in International Business and Finance, 21, 326-341. http://dx.doi.org/ 10.1016/j.ribaf.2006.09.001

Narayan, P. K., \& Narayan, S. (2010). Modelling the impact of oil prices on Vietnam's stock prices. Applied Energy, 87(1), 356-361. http://dx.doi.org/10.1016/j.apenergy.2009.05.037

Noland, M. (2000). The Philippines in the Asian Financial Crisis: How the Sick Man Avoided Pneumonia. Asian Survey, 40(3), 401-412. http://dx.doi.org/10.2307/3021153

Ono, S. (2011). Oil price shocks and stock markets in BRICs. The European Journal of Comparative Economics, 8(1), 29-45.

Park, J., \& Ratti, R. A. (2008). Oil price shocks and stock markets in the US and 13 European countries. Energy Economics, 30, 2587-2608. http://dx.doi.org/10.1016/j.eneco.2008.04.003

Philippine Stock Exchange. (2011). Policy on Index Management. [Online] Available: http://pse.com.ph/stockMarket/indexRules.html?tab=0 (May 2011)

Philippine Stock Exchange. (2014). Recomposition of PSE Indices - CN- No.2014-0043. [Online] Available: http://www.pse.com.ph/stockMarket/circulars.html (August 27, 2014)

Philippine Stock Exchange Edge. (2014). Company List. [Online] Available: http://edge.pse.com.ph/companyDirectory/form.do

Sadorsky, P. (1999). Oil price shocks and stock market activity. Energy Economics, 21, 449-469. http://dx.doi.org/10.1016/s0140-9883(99)00020-1

Sadorsky, P. (2001). Risk factors in stock returns of Canadian oil and gas companies. Energy Economics, 23, 17-28. http://dx.doi.org/10.1016/s0140-9883(00)00072-4

Seghal S., \& Kapur, R. (2012). Relationship between Oil Price Shocks and Stock Market Performance: Evidence for Select Global Equity Markets. Vision, 16(2), 81-92. http://dx.doi.org/10.1177/097226291201600201

Shahbaz, M., Ahmed, N., \& Ali, L. (2008). Stock Market Development and Economic Growth: Ardl Causality in Pakistan. International Research Journal of Finance and Economics, (14), 182-195.

Sims, C. A. (1980). Macroeconomics and Reality. Econometrica, 48(1), 1-48. 
http://dx.doi.org/10.2307/1912017

Soucek, M., \& Todorova, N. (2013). Economic significance of oil price changes on Russian and Chinese stock markets. Applied Financial Economics, 23(7), 561-571. http://dx.doi.org/10.1080/09603107.2012.732685

Unal, G., \& Korman, D. (2012). Analysis Of Extreme Dependence Between Istanbul Stock Exchange And Oil Returns. The International Journal of Business and Finance Research, 6(4), 113-124.

Wang, Y., Wu, C., \& Yang, L. (2013). Oil price shocks and stock market activities: Evidence from oil-importing and oil-exporting countries. Journal of Comparative Economics, 41, 1220-1239. http://dx.doi.org/10.1016/j.jce.2012.12.004

\section{Copyright Disclaimer}

Copyright for this article is retained by the author(s), with first publication rights granted to the journal.

This is an open-access article distributed under the terms and conditions of the Creative Commons Attribution license (http://creativecommons.org/licenses/by/3.0/). 